\title{
Relationship between the Obstetric Profile of Mothers and the Need for Newborn Resuscitation
}

Maria De Fátima De Lima1, Danilo Ferreira de Sousa², Tâmisa Cruz Sampaio³, Natália Moreira Garcia Feitosa ${ }^{4}$, Maria de Fátima Vasques Monteiro ${ }^{5}$, André Alencar Moreira ${ }^{6}$, Hermes Melo Teixeira Batista7, Anderson Milfont Feitosa de Oliveira7, Adalberto Cruz Sampaio ${ }^{8}$

\section{Abstract}

In most cases, the births in Brazil take place in a quiet way. However, as a transitional period susceptible to complications, the newborn may unexpectedly require resuscitation. Therefore, the presence of at least one trained professional in case of need to perform resuscitation is necessary. This study aimed to correlate the obstetric profile of mothers with neonatal resuscitation. The quantitative approach was used. Data were collected between February and March 2016, in a referral hospital in obstetrics, in a city of Cariri Region. To collect the data, we used a form that included questions related to the purpose of the study. After collection, the data were analyzed, and organized in Excel 2010 spreadsheets program, and presented through tables and graphs built in Word and Excel 2010 programs. We performed a Pearson correlation test with SPSS 22.0 program. With this study, it was concluded that there is a great relationship between the need for resuscitation maneuver and diseases during pregnancy, stock time and type of delivery. Also, deserves due attention to the statistical relationship between death and use of medication and meconium. The obstetric patient profile is important and must be considered in the clinical evolution of the newborn. Many of these factors can be identified even during pregnancy, during prenatal care, thus enabling the implementation of interventions in a timely manner.

\section{Introduction}

The neonatal period includes the time from birth until the first 28 days (1). Newborns are classified according to gestational age (GA)

\section{Keywords}

Newborn; Maneuvers; Resuscitation. 
in newborn to term (NBT), preterm (PTN) and postterm (PTN). They can be further classified according to weight, as follows: appropriate for gestational age (AGA), large for gestational age (LGA) and small for gestational age (SGA) [2].

At birth, the newborn (NB) need immediately to take its vital functions that were previously performed by the placenta. The first 24 hours of life are known as a transition period, making it a difficult and dynamic stage in human life. This period is known as the process of adaptation to extrauterine life, placing the newborn in vulnerable situations because it involves anatomical and functional changes in all newborn's organs and systems when it is removed from its dependent habitat [3].

Almeida et al. point out that in Brazil around three million children are born per day, and that $98 \%$ of births are in hospitals. Most of these births take place in a quiet way [4]. However, because it is a vulnerable period for both mother and newborn $(\mathrm{NB})$, resuscitation may be needed unexpectedly, so professional presence is indispensable well trained as a pediatrician.

At birth, $10 \%$ of newborns need resuscitation in the delivery room to adapt them to take their spontaneous respiratory movements. In practice, it seems simple. However, it is clearly increasing neonatal mortality. Recalling that, in Brazil, in 2008, $20 \%$ of neonatal deaths occurred early, between 0-7 days of life [5].

To Martins et al. there are possibilities for improvement of perinatal indicators. Thus, the Family Health Strategy (ESF) needs to commit to working seamlessly with the hospital, offering continuous and shared assistance throughout the pregnancy, childbirth and postpartum. Thus, early possible complications, even prenatally can be identified, to be adopted immediate neonatal resuscitation behavior soon after birth(6).

In this sense, there is the need to know the causes of neonatal resuscitation, as this knowledge may offer benefit to this issue in the neonatal area, generating awareness and investment opportunities in the newborn health.

This study will contribute with accurate information in order to alert professionals of neonatology team, as well as expand its investment expectations in neonatal care, sensitize managers and population; and also as a theoretical basis for further studies on this subject.

Thus, the aim of this study is to correlate the obstetric profile of mothers with neonatal resuscitation.

\section{Method}

This is a descriptive, documental, retrospective with a quantitative approach research, seeking to improve the factors involved in the research. The survey was conducted in a hospital in the region of Cariri. The hospital was founded in 1990, is a reference in obstetrics for nine counties. It is a medium-sized institution linked to the Unified Health System (SUS) with assistance, education and extension roles being a reference in the region.

The population consisted of all medical records of infants who were born at the hospital in the study. The sample consisted of 197 medical records, which had the following inclusion criteria: the medical records of newborns from 0 to 28 days of life; being born between the years 2014-2015; and requiring resuscitation. Of the 197 medical records of newborns, 91 were from the year 2014, and 106 were 2015.

Exclusion criteria were: all newborns records that were ineligible and records of newborns that were not born in that hospital.

The instrument used for data collection was a form. A letter was sent to the institution in order to receive its authorization to carry out data collection. To start collecting data, a trustee term was signed, ensuring that they would be used only data related to the research in question and that they would be used only for academic purposes while guaranteeing the confidentiality of the information contained in the records. 
Data collection took place from Monday to Friday, between 07 and 11 o'clock in the morning.

Data were analyzed quantitatively and organized through Excel 2010 spreadsheets program and presented in tables and graphs that were built in programs. The Pearson correlation test was also performed to verify the relationship between obstetric variables and the resuscitation maneuver. For this, we used the SPSS 22.0.

The study followed the standards for human research of Resolution 466/12 of the National Health Council of Brazil (BRASIL, 2012), which regulates the guidelines expressing the respect, dignity, and protection related to humans when directly involved in the research.

\section{Results And Discussion}

The results achieved are related to the socio-demographic, reproductive and obstetrical profile of newborns' mothers who required resuscitation, as well as the characteristics, complications, and outcome of newborns.

There are several factors that cause risks during pregnancy and the health of newborns. Many of these factors may be present even before pregnancy. Maternal characteristics are extremely important, because, researching these, you can identify these factors may lead to complications on the health of newborn. In this sense, we described the characteristics of newborns' mothers in the study (Table 1 ).

The individual aspects and the unfavorable sociodemographic situation as the low level of education, unsafe marital status, alcohol use, and smoking, among other factors, contribute to a high-risk pregnancy and may cause adverse consequences for both maternal and fetus health [7[).

Maternal age under 16 and over 35 is considered a risk factor for pregnancy, and also to the need for resuscitation [8].

In this study, with relation to age, considered as a risk pregnancy, 20 (10\%) of the mothers were older
Table 1. Distribution of the sample according to the sociodemographic profile of the Mothers of newborns who required resuscitation. 2016

\begin{tabular}{|l|c|c|}
\hline \multicolumn{1}{|c|}{ Characteristics } & N & $\%$ \\
\hline Age & & \\
\hline Under 16 years & 3 & 2 \\
\hline 16 to 35 years & 171 & 88 \\
\hline Over 35 Years & 20 & 10 \\
\hline Race & & \\
\hline White & 10 & 5 \\
\hline Mulattos & 182 & 94 \\
\hline Black & 2 & 1 \\
\hline Marital Status & & \\
\hline Single & 63 & 32 \\
\hline Married & 109 & 56 \\
\hline Stable union & 21 & 11 \\
\hline Widow & 1 & 1 \\
\hline Education & & \\
\hline Illiterate & 1 & 0.5 \\
\hline Incomplete primary education & 62 & 32 \\
\hline Complete primary education & 45 & 23 \\
\hline Complete high school & 79 & 41 \\
\hline Incomplete Higher Education & 4 & 2 \\
\hline Complete Higher Education & 3 & 1.5 \\
\hline Smoker & 131 & 93 \\
\hline Yes & Source: direct search, 2016 \\
\hline No & & \\
\hline
\end{tabular}

than 35 years and 3 (2\%) were younger than 16 years. In this sense, taking into account the statement of the Ministry of Health [8] regarding maternal age, it follows that this study maternal age can is associated with the need for resuscitation for newborns.

Also regarding maternal age, the study of Mendonça, in which they sought to identify obstetric and neonatal risk situations that favored to the meconium aspiration syndrome, the results are similar to those. In this study, 5\% of mothers were aged over 35 years [9]. 
Regarding marital status, note that despite the majority are married or living in a stable union, a significant number of mothers were single. These results also resemble the study Mendonca, in which $25 \%$ of the progenitors lived in insecure marital status or were single [9]. These authors point out, among others, the uncertain marital status as a gestational risk factor.

It was found that regarding education, 108 (55.5\%) had up to eight years of study. The maternal education and socioeconomic status constitute significant risk factors for child survival.

Regarding the smoking habit, 13 (7\%) mothers were smokers. In Galão study on the effects of maternal smoking during pregnancy and perinatal complications, smoking during pregnancy can cause harmful effects on pregnancy and fetus [10].

The presence of one or more obstetric risk factors may influence the development of problems during pregnancy and may adversely impact the health of the neonate. A description of the obstetrical profile of mothers was performed to identify and associate possible causes of complications in newborns (Table 2).

Regarding the number of previous pregnancies, 94 (48\%) mothers had one to three pregnancies. In Bentlin et al. study, in which an evaluation of neonatal resuscitation in a university tertiary referral hospital was made, the results are similar to this study. It was found in this study that most mothers were multiparous with an average of two previous pregnancies [11].

Most mothers attended seven or more prenatal visits, which can be seen as a positive aspect. Similar to the study of Benites; Casey on the profile of the newborn in an Intensive Care Unit, the results show that $90.2 \%$ of pregnant women attended some type of prenatal care [12]. The results on the number of prenatal visits were satisfactory. However, the authors infer that prenatal conducted did not produce the expected resoluteness.

Although the number of pre-natal visits performed, it was found that there are still unfavorable
Table 2. Distribution of the sample according to the obstetric profile and complications during pregnancy of newborns' mothers who required resuscitation maneuver. 2016.

\begin{tabular}{|c|c|c|}
\hline Obstetric Profile & $\mathbf{N}$ & $\%$ \\
\hline \multicolumn{3}{|l|}{ Previous Pregnancy } \\
\hline None & 93 & 47 \\
\hline 1 to 3 pregnancies & 94 & 48 \\
\hline 4 or more pregnancies & 7 & 5 \\
\hline \multicolumn{3}{|l|}{ Abortion } \\
\hline Yes & 28 & 14 \\
\hline No & 166 & 86 \\
\hline \multicolumn{3}{|c|}{ Number of Prenatal consultations } \\
\hline None & 11 & 6.0 \\
\hline 2 to 4 consultations & 27 & 14.0 \\
\hline 5 to 6 consultations & 33 & 17.0 \\
\hline 7 or more consultations & 123 & 63.0 \\
\hline \multicolumn{3}{|l|}{ Diseases in the pregnancy } \\
\hline Yes & 125 & 64 \\
\hline No & 69 & 36 \\
\hline \multicolumn{3}{|l|}{ Use of Medications } \\
\hline Yes & 75 & 39 \\
\hline No & 119 & 61 \\
\hline \multicolumn{3}{|l|}{ Meconium } \\
\hline Yes & 58 & 30 \\
\hline No & 136 & 70 \\
\hline \multicolumn{3}{|l|}{ Tempo de Bolsa } \\
\hline Integra & 150 & 77 \\
\hline Rota & 44 & 23 \\
\hline \multicolumn{3}{|l|}{ Type of delivery } \\
\hline Vaginal & 108 & 56 \\
\hline Cesarean & 86 & 44 \\
\hline \multicolumn{3}{|c|}{ Source: direct search, 2016.} \\
\hline
\end{tabular}

situations. We see then, the need to improve prenatal care in the item quality that falls short.

Regarding prenatal care, the Ministry of Health $(\mathrm{MOH})$ said that this, when done properly, provides the identification of problems and risk factors in a timely manner to carry out the appropriate interventions. And, currently, the major challenge is the quality of care, not just the number of consultations [11]. 
For the diseases occurred during pregnancy, 125 (64\%) progenitors showed some disease. Of these, most had urinary infection $(40,32 \%)$, IPV (21; $16.8 \%$ ), and / or urinary tract infection and vulvovaginitis concomitantly (46; 36.8\%). Corroborating these results, Benites's study data; Casey (2006) shows that the majority (80\%) of the diseases brought by the mothers were urinary tract infections. These authors also reported that the urinary tract infection is the most common urinary injury during pregnancy, may cause serious complications on fetal health [12].

Regarding the use of medicinal drugs during pregnancy, 119 (61\%) mothers did not use, and 75 (39\%) used some medicine. The most commonly used drugs were cephalexin, hydralazine, and methyldopa.

It is observed in this study that 58 (30\%) mothers had meconium. According to Mendonça [9] , complications such as perinatal infection and hypoxia can lead to the elimination of meconium in the uterus, it may lead neonates to develop meconium aspiration syndrome (MAS) and, consequently, require resuscitation.

In this study, we can relate the presence of meconium to the need of resuscitation, since the presence of meconium is considered a factor that has contributed to the increased need for neonatal resuscitation, so fitting, the professional team to evaluate the fetus in the antepartum and the labor and learn early to identify the reasons that lead to the elimination of meconium [9].

Regarding the type of delivery most had a vaginal delivery (108-56\%) and 86 (44\%) had a cesarean section. These results are similar to those found in Bentlin study, in which the majority (64\%) of women delivered vaginally [11].

In the case of caesarean delivery in this study, 86 $(44 \%)$ of pregnant women who received an indication for this type of delivery, 29 (34\%) of these received because of fetal distress. These data are also similar to those mentioned in the study of Bentlin, in which fetal distress was the prevalent cause of cesarean delivery indication [11].

Still on the type of delivery, in this study, 36 (18.5\%) of mothers who had a cesarean delivery, this occurred between 37 and 39 weeks of gestation. Cesarean delivery performed between 37 and 39 weeks of pregnancy, even in the absence of risk factors for antenatal asphyxia, also increases the risk of newborn require ventilation.

All these mentioned factors can be avoided or have their consequences reduced, through strategies aimed at provision of assistance in a holistic and effective way by all the professionals involved in the care during the pregnancy period and birth.

The complications occurred with newborns may be determined by both the need for resuscitation and for the clinical outcome of these, as described in the following table (Table 3).

Table 3. Distribution of the sample as the complications occurred with newborns requiring resuscitation. 2016.

\begin{tabular}{|l|c|c|}
\hline \multicolumn{1}{|c|}{ Complications } & N & $\%$ \\
\hline Circular de cordão & 54 & 27 \\
\hline Yes & 143 & 73 \\
\hline No & & \\
\hline Arrest & 161 & 82 \\
\hline Respiratory & 36 & 18 \\
\hline Cardiorespiratory & & \\
\hline Reanimation manoeuvres & 162 & 82 \\
\hline Simple & 35 & 18 \\
\hline Advanced & & \\
\hline Hospitalized & 81 & 41 \\
\hline Yes & 116 & 59 \\
\hline No & & \\
\hline Transferred & 28 & 14 \\
\hline Yes & 169 & 86 \\
\hline No & & \\
\hline Death & 18 & 9 \\
\hline Yes & 177 & 90 \\
\hline No & 2 & 1 \\
\hline Unknown & Source: direct search, 2016 \\
\hline
\end{tabular}


According to Abrantes et al. (2015), cardiorespiratory arrest, is characterized by the sudden suspension of the heartbeat, breathing movements, and the immediate loss of consciousness, causing brain damage and death [13].

According to Bentlin et al. (2005), neonatal resuscitation, is divided into four categories, they are initial steps, balloon ventilation, and mask or tracheal tube, cardiac massage and administration of drugs or fluids. Most newborns need only the initial steps; however, for those who require some intervention, the primary action is to establish adequate ventilation. A small number of newborns will require the performing cardiac massage or medication administration [11].

Regarding the type of resuscitation procedure performed in neonates, the simple maneuver represented the majority (162; $82 \%)$. In the study of Bentlin et al. (2005), the results show that in most newborns only the first initial steps of resuscitation were performed [11, 14].

Regarding the clinical outcome of newborns in the study, it is clear that 81 (41\%) were hospi- talized, 28 (14\%) were transferred, and 18 (9\%) died, and $2(1 \%)$ had not information about its outcome. With regard to the transfer and death of newborns, the results of this study are similar to those found in the study of Mendonça et al. (2015), in which $5 \%$ of newborns were transferred and $15 \%$ died [9].

As Bentlin et al. (2005), the passage from intraenvironment to extrauterine is a stage of human development very vulnerable to complications. The incidents occurred during this period may have permanent consequences in individuals' lives [11].

Factors such as the characteristics related to the mother and the newborn, as well as the complications that occur during pregnancy and during delivery may determine the need for prompt intervention. Among these, there are the resuscitation maneuvers, which must be carried out correctly and effectively by trained professionals to perform them.

Table 4 represents a correlation test to verify the relationship between the variables and the resuscitation or death.

Table 4. Correlations.

\begin{tabular}{|c|c|c|c|c|c|c|c|c|c|c|}
\hline & $\begin{array}{c}\text { Previous } \\
\text { pregnancies }\end{array}$ & Abortion & $\begin{array}{c}\begin{array}{c}\text { Number } \\
\text { of } \\
\text { consultations }\end{array}\end{array}$ & $\begin{array}{l}\text { Diseases } \\
\text { in } \\
\text { pregnancy }\end{array}$ & $\begin{array}{c}\text { Use } \\
\text { of } \\
\text { medication }\end{array}$ & Meconium & $\begin{array}{l}\text { Break } \\
\text { time }\end{array}$ & \begin{tabular}{|c|} 
Type \\
of \\
delivery
\end{tabular} & $\begin{array}{c}\text { Maneuver } \\
\text { resuscitation }\end{array}$ & Death \\
\hline \multicolumn{11}{|c|}{ Previous pregnancies } \\
\hline $\begin{array}{l}\text { Pearson's } \\
\text { correlation }\end{array}$ & 1 & $1,000^{*}$ &,- 704 & $-1,000 *$ & $1,000^{\star}$ & $1,000^{*}$ & $-1,000 *$ & $-1,000 *$ & $-1,000 *$ &, 578 \\
\hline $\begin{array}{l}\text { Sig. ( } 2 \\
\text { extremities) }\end{array}$ & & . &, 503 & . & & & & & &, 608 \\
\hline \multicolumn{11}{|l|}{ Abortion } \\
\hline $\begin{array}{l}\text { Pearson's } \\
\text { correlation }\end{array}$ & $1,000 *$ & 1 & $1,000^{*}$ & $-1,000^{*}$ & $1,000 *$ & $1,000^{*}$ & $-1,000 *$ & $-1,000 *$ & $-1,000 *$ & 1,000 * \\
\hline $\begin{array}{l}\text { Sig. ( } 2 \\
\text { extremities) }\end{array}$ & . & & . & . & . & & . & . & . & \\
\hline \multicolumn{11}{|c|}{ Number of consultations } \\
\hline $\begin{array}{l}\text { Pearson's } \\
\text { correlation }\end{array}$ & -704 & $1,000^{*}$ & 1 & $-1,000^{*}$ & $1,000^{*}$ & $1,000^{*}$ & $-1,000 *$ & $-1,000 *$ & $-1,000^{*}$ &, 173 \\
\hline $\begin{array}{l}\text { Sig. ( } 2 \\
\text { extremities) }\end{array}$ &, 503 & . & & . & & & . & . & & 889 \\
\hline
\end{tabular}




\begin{tabular}{|c|c|c|c|c|c|c|c|c|c|c|}
\hline & $\begin{array}{c}\text { Previous } \\
\text { pregnancies }\end{array}$ & Abortion & $\begin{array}{c}\begin{array}{c}\text { Number } \\
\text { of }\end{array} \\
\text { consultations }\end{array}$ & $\begin{array}{l}\text { Diseases } \\
\text { in } \\
\text { pregnancy }\end{array}$ & $\begin{array}{c}\text { Use } \\
\text { of } \\
\text { medication }\end{array}$ & Meconium & $\begin{array}{l}\text { Break } \\
\text { time }\end{array}$ & $\begin{array}{c}\text { Type } \\
\text { of } \\
\text { delivery }\end{array}$ & $\begin{array}{c}\text { Maneuver } \\
\text { resuscitation }\end{array}$ & Death \\
\hline \multicolumn{11}{|c|}{ Diseases in pregnancy } \\
\hline $\begin{array}{l}\text { Pearson's } \\
\text { correlation }\end{array}$ & $-1,000 *$ & $-1,000 *$ & $-1,000 *$ & 1 & $-1,000 *$ & $-1,000 *$ & $1,000 *$ & $1,000 *$ & $1,000 *$ & $-1,000 *$ \\
\hline $\begin{array}{l}\text { Sig. ( } 2 \\
\text { extremities) }\end{array}$ & . & . & . & & . & . & . & $\cdot$ & . & . \\
\hline \multicolumn{11}{|c|}{ Use of medication } \\
\hline $\begin{array}{l}\text { Pearson's } \\
\text { correlation }\end{array}$ & $1,000 *$ & 1,000 * & $1,000 *$ & $-1,000 *$ & 1 & $1,000 *$ & $-1,000 *$ & $-1,000 *$ & $-1,000 *$ & 1,000 * \\
\hline \multicolumn{11}{|l|}{$\begin{array}{l}\text { Sig. ( } 2 \\
\text { extremities) }\end{array}$} \\
\hline \multicolumn{11}{|l|}{ Meconium } \\
\hline $\begin{array}{l}\text { Pearson's } \\
\text { correlation }\end{array}$ & $1,000 *$ & $1,000 *$ & $1,000 *$ & $-1,000^{*}$ & $1,000 *$ & 1 & $-1,000^{*}$ & $-1,000 *$ & $-1,000 *$ & $1,000 *$ \\
\hline $\begin{array}{l}\text { Sig. ( } 2 \\
\text { extremities) }\end{array}$ & . & & . & . & . & & & . & . & . \\
\hline \multicolumn{11}{|l|}{ Break time } \\
\hline $\begin{array}{l}\text { Pearson's } \\
\text { correlation }\end{array}$ & $-1,000 *$ & $-1,000 *$ & $-1,000^{*}$ & $1,000 *$ & $-1,000 *$ & $-1,000 *$ & 1 & $1,000 *$ & $1,000 *$ & $-1,000 *$ \\
\hline $\begin{array}{l}\text { Sig. ( } 2 \\
\text { extremities) }\end{array}$ & . & . & . & . & . & . & & . & . & . \\
\hline \multicolumn{11}{|c|}{ Type of delivery } \\
\hline $\begin{array}{l}\text { Pearson's } \\
\text { correlation }\end{array}$ & $-1,000 *$ & $-1,000 *$ & $-1,000 *$ & $1,000 *$ & $-1,000 *$ & $-1,000 *$ & $1,000 *$ & 1 & $1,000 *$ & $-1,000 *$ \\
\hline $\begin{array}{l}\text { Sig. ( } 2 \\
\text { extremities) }\end{array}$ & . & & . & & . & . & & & . & \\
\hline \multicolumn{11}{|c|}{ Maneuver resuscitation } \\
\hline $\begin{array}{l}\text { Pearson's } \\
\text { correlation }\end{array}$ & $-1,000 *$ & $-1,000 *$ & $-1,000 *$ & $1,000 *$ & $-1,000 *$ & $-1,000 *$ & $1,000 *$ & $1,000 *$ & 1 & $-1,000 *$ \\
\hline $\begin{array}{l}\text { Sig. ( } 2 \\
\text { extremities) }\end{array}$ & . & & . & . & . & . & & . & & . \\
\hline \multicolumn{11}{|l|}{ Death } \\
\hline $\begin{array}{l}\text { Pearson's } \\
\text { correlation }\end{array}$ &, 578 & $1,000 *$ & 173 & $-1,000 *$ & $1,000 *$ & $1,000 *$ & $-1,000 *$ & $-1,000 *$ & $-1,000 *$ & 1 \\
\hline $\begin{array}{l}\text { Sig. ( } 2 \\
\text { extremities) }\end{array}$ &, 608 & & ,889 & & . & . & & . & . & \\
\hline
\end{tabular}

Source: prepared by the authors. *: The correlation is significative in level 0,01 (2 extremities).

The correlation test is a variable ranging from -1 (perfect negative correlation), 0 (no correlation) and 1 (perfect positive correlation). It deserves a proper attention to the relationship between the need for resuscitation maneuver and diseases during pregnancy and type of delivery. It is also worth noting the statistical relationship between death and use of medication and meconium. The obstetric patient profile is important and should be considered in the clinical evolution of the newborn. 


\section{Conclusion}

On the presented results, it can be inferred that many factors can influence the occurrence of complications and the need to perform resuscitation. Many of these factors can be identified even during pregnancy during prenatal care, thus enabling the implementation of interventions in a timely manner. Therefore, we emphasize the importance of quality of care in this period.

It is essential that health professionals plan and execute effectively, the promotion, prevention and care actions in the pregnancy and newborn. These actions are of great importance, as they influence the health situation of people since the neonatal period.

\section{References}

1. Oliveira DMR. de. Influência da manobra de compressãodescompressão: uma abordagem fisioterapêutica na UTI neonatal. p. 7-8, 2014. Disponível em: <http:// www.dspace. bc.uepb.edu.br>. Acesso em: 08 ago. 2015.

2. Souza $A B G$. Enfermagem neonatal: Cuidado integrado ao recém-nascido. 1 ed. São Paulo: Martinari, 2011. p. 57-58 e 65.

3. Rego JD. Reanimação Neonatal. Revista de pediatria SOPERJ. v. 13, n. 2, p 10-13, dez. 2012. Disponível em: <httpllwww.sbp. com.br>. Acesso em: 18 ago. 2015.

4. Almeida MFB de; Guinsburg R. Reanimação neonatal em sala de parto: Documento Científico do Programa de Reanimação Neonatal. p. 2, 2013. Disponível em: <http://www.sbp.com.br/ pdfs/PRN-SBP-Reanima\%C3\%A7\%C3\%A>. Acesso em: 19 set. 2015.

5. Faria CS et al. Morbilidad y mortalidad entre reciénnacidos de riesgo: una revisión bibliográfica. Enfermería Global. v. 13, n. 36, p. 298-309, 2014. Disponível em: <http://scielo.isciii. es/scielo.php?pid=S1695-61412014000400017\&script=sci arttext\&t|ng=pt>. Acesso em: 01 set. 2015 al. "Impact of prenatal and/or postnatal growth problems in low birth weight preterm infants on school-age outcomes: an 8-year longitudinal evaluation." Pediatrics 118.3 (2006): 1078-1086

6. Martins $F$ et al. Óbitos perinatais investigados e falhas na assistência hospitalar ao parto. p. 39, 2013. Disponível em: $<$ http://www.scielo.br/scielo.php?Script=sci arttext\&pid $=$ =\$1519-382920140002001372013 > . Acesso em: 25 ago. 2015.

7. Brasil, Ministério da Saúde. Gestação de alto risco. 5a. Ed. Brasília, 2012.
8. Brasil, Ministério da Saúde. Atenção à Saúde do Recém-Nascido. $2^{a}$ Ed. Brasília, 2012b.

9. Mendonça SD et al. Síndrome da aspiração meconial: identificando situações de risco obstétricos e neonatais. J. res.: fundam. care. Online. v. 7, n. 3, p. 2910-2918, 2015.

10. Galão $A O$ et al. Efeitos do fumo materno durante a gestação e complicações perinatais. Rev. HCPA. v. 29, n. 3, p. 218-224. 2009.

11. Bentlin MR et al. Reanimação neonatal em um hospital universitário de nível terciário. Rev. Ciênc. Méd. v. 14, n. 1, p. 23-31, 2005. Disponível: <http://periodicos.puc-campinas.edu. br/seer/index.php/cienciasmedicas/article/viewFile/1191/1166>. Acesso em: 14 abr. 2016.

12. Casey, PH., et

13. Abrantes AWB et al. Conhecimentos, atitudes e práticas da enfermagem sobre a parada cardiorrespiratória em unidade de cuidados intermediários de neonatologia: estudo qualitativo no nordeste do Brasil. Revista brasileira de crescimento e desenvolvimento humano. v. 25, n. 1, p. 97-101, 2015. Disponível em: <https://scholar.google.com.br/scholar?as_ylo=2014\&q=m anobras+de+reanima\%C3\%A7\%C3\%A3o+neonatal\&hl=ptBR\&lr=lang pt\&as sdt=0,5>. Acesso em: 20 set. 2015.

14. Benites PT, Nunes CB. Conhecendo o perfil do recém-nascido em uma Unidade de Terapia Intensiva. Ensaios e Ciência. v. 10, n. 1, p. 33-40, 2006. Disponível em: <http://www.redalyc.org/ pdf/260/26012809003.pdf>. Acesso em: 14 abr. 2016.

\section{Publish in International Archives of Medicine}

International Archives of Medicine is an open access journal publishing articles encompassing all aspects of medical science and clinical practice. IAM is considered a megajournal with independent sections on all areas of medicine. IAM is a really international journal with authors and board members from all around the world. The journal is widely indexed and classified Q2 in category Medicine. 